DOI: https://doi.org/10.32839/2304-5809/2019-6-70-71

UDC 371.3

Shevchenko Maryna, Bikezina Anastasia

Donbass State Teacher Training University

\title{
DISCOURSE ANALYSIS IN COGNITIVE LINGUISTICS
}

Summary. The article discusses the origins of discourse analysis based on the traditions of ethno-linguistics. The author highlighted them ai views on the emergence of discourse analysis. Indicates the path of the process of formation of analysis, linguist sand linguistic schools that have worked on this issue. The main task of US ethnolinguistics was to study the languages of the Indian tribes of North and Central America, focusing on the recording and analysis of verbal texts, as well as the study of the interaction of the languages of the Indians and Indo-European languages. It was interesting to mention that the language was considered by the scientist in two respects: firstly, as a decision that takes the speaker on what to say and what is not, and, secondly, as mechanisms and structures that are available to the speaker to implement those decisions in order to communicate with another person.

Keywords: discourse analysis, linguistics, ethnolinguistics, discourse, communicative method.

Шевченко М.Ю., Бікезіна А.Д.

Донбаський державний педагогічний університет

\section{ДИСКУРСНИЙ АНАЛІЗ В КОГНІТИВНІЙ ЛІНГВІСТИЦІ}

Анотація.У статтірозглянутопитаннявитоків дискурс-аналізу, щобазувався на традиціяхетнолінгвістики. Автором виділено основні погляди на питання виникнення дискурсного аналізу. Зазначаються шляхи процесу становлення аналізу, лінгвісти та лінгвістичні школи, які працювали над цим питанням. Поняття дискурсу є одним із основних понять сучасної прагматичної лінгвістики та лінгвістики тексту. Сучасні уявлення про дискурс віддзеркалюють увесь хід лінгвістичної науки. У першій половині XX ст. мовознавство протягом досить тривалого періоду було зосереджене на вивченні однієї 3 двох діалектично зв'язаних сторін мови мовній системі, але, починаючи з другої половини 60-х рр., центр уваги лінгвістів переноситься на іншу сторону цієї діалектичної єдності мовленневу діяльність та її продукт - дискурс, формальні характеристики якого були отримані у 1952 р. З. Херрісом. Цей складний соціолінгвістичний феномен сучасного комунікативного середовища має довгу і багату історію свого розвитку, проте як термін в лінгвістиці з'явився лише у 50-х рр. ХХ ст. Термін «дискурс» увів у використання Ю. Хабермас для позначення «виду мовленневої комунікації, що пропонуе раціональний критичний розгляд цінностей, норм та правил, які знаходяться у соціальному житті» [4]. Беручи до уваги вік дискурсу, що є не дуже довгим з точки зору лінгвістичної науки, і незважаючи на те, що вивченням даного поняття займалась невелика кількість науковців, на сучасному етапі дослідження проблеми породження та функціонування дискурсу виступає одним з провідних напрямів світової лінгвістики. Сфера вживання терміну «дискурс» стае надзвичайно широкою, а дискурсивний аналіз текстів все частіше застосовуеться науковцями, що і визначає актуальність цієї статті. Традиційно дискурс мав значення упорядкованого письмового, але найчастіше мовного, повідомлення окремого суб'єкта. В останні десятиліття термін дістав широке поширення в гуманітаристиці і набув нових відтінків значення. Часте ототожнення тексту і дискурсу зв'язано, по-перше, з відсутністю в деяких европейських мовах терміна, еквівалентного фор.-англ, discours(e), а по-друге, з тим, що раніше в обсяг поняття дискурс включалася лише мовна практика.

Ключові слова: дискурс ний аналіз, лінгвістика, етнолінгвістика, дискурс, комунікативний метод.

Tntroduction. In recent decades, discourse analysis is one of the most popular research methods in the field of social sciences and the humanities. Mainly formulated as a response to positivism, discourse analysis formed part of what has been categorised as an interpretative or 'linguistic turn' (Fischer and Forrester, 1993) in urban studies in the 1980s. Since the 1990s, housing studies have attempted to draw upon a wider multidisciplinary theoretical tradition, providing detailed analysis, using interpretative frameworks, and qualitative methodologies.

According to many scholars, as a special method of scientific philological research, discourse analysis is based on the traditions of American ethnolinguistics (or anthropological linguistics) and Czech structuralism.

Relevance. The research is beyond doubt, as today's discursive analysis in linguistics is one of the most popular research methods in the field of social sciences and the humanities.
The subject of the study is the process of the formation of a discussion analysis in linguistics.

The subject of the study is diverse linguistic schools and prominent linguists.

The aim of the study is to study the views on the issue of discussion analysis in linguistics of the past centuries and today. Finding out the reasons for the formation of this discipline and getting acquainted with the activities of the leaders of various linguistic schools.

Analysis of research and publications. Discourse-analysis was studied by such linguists as J. Gerder, E. Sepir, W. Worff, W. Mathesius, J. Mukarzhovsky.

Basic material. Among the ethno-linguistic schools, the school of Americanethnolinguistics, founded by Franz Boas, was of great importance for the development of discourse-analysis.

The main task of US ethnolinguistics was to study the languages of the Indian tribes of North and Central America, focusing on the recording 
and analysis of verbal texts, as well as the study of the interaction of the languages of the Indians and Indo-European languages. The conceptual foundations of American traditions in ethnolinguistics studies are also seen in the works of J. Gerder and W. von Humboldt, where the emphasis was also placed on ethnographic material and the study of languages that do not have written traditions. Back in the early 19 th century W. von Humboldt wrote: "A person speaks in order not only to convey messages, while at the same time achieving goals that are subordinated to joint activities. In order to understand the content of speech, it is necessary to know the activities in which it was created and perceived" [1, p. 11-13].

According to us, this statement accurately shows that using the concept "discourse", W. von Humboldt was one of the first who emphasized need of accounting of extralinguistic factors for the correct understanding of a statement.

The beginning of ethnolinguistics, most linguists associate with the name of the famous American ethnologist F. Boas, who "made a theoretical and methodological revolution in entology" [5, p. 13].

Subsequently, ethnolinguisticsin the United States was successfully developed in the works of his disciples E. Sepir, W. Whorf and followers of R. Hoyer, D. Lee, J. Clarkson, C. Voglina and Z. Harris in 1952 in the article for the first time used the concept "discourse analysis".

The emergence of Czech structuralism dates back to 1952 , when the well known linguist W. Mathesiusfounded the "Czech linguistic circle" [3, p. 23].

Structuralism is a methodology of the humanities, which analyzes a particular industry, as a complex system of interrelated parts. In linguistics, structuralism developed on the basis of the ideas of F. de Sosiur, with the greatest contribution to their development and application made by the members of the Czech (or Prague) linguistic circle R. Jacobson, Y. Mukarzhovsky.

The main idea of the Prague Circle was the interpretation of language as a functional system of means of expression, which serves a certain purpose. Based on these ideas, members of the circle developed the basics of functional grammar, studied functional styles and languages.

The term "functional style" is sometimes used in conjunction with the term "discourse". However they are not interchangeable anyway. According to us, it can be shown accurately, having analysed definitions of these terms.

The functional style is understood as a set of methods of selection and messages of the speech means which are functionally caused by the contents, the purpose and circumstances of communication [4, p. 12].

Consequently, we can conclude that functional stylistics studies the linguistic peculiarities of texts at a rather high level of generalization, abstracting from concrete, real speech. At the same time, "discourse" is regarded as different types of speech and speech works, which are interpreted and associated with each other, taking into account non-lexical factors. This shows that discourse is based not on the functional-stylistic principle of the separation of communicative spheres and speech systems.

The main criterion for allocating discourse, unlike functional style, is not the form of social con- sciousness, but the content-semantic similarity of texts. But, one can not deny the inextricable link between these terms: the term "discourse" arose precisely on the basis of the term "functional style".

As noted above, for the first time the concept of "discourse analysis" was used in 1952 by the American linguist Z. Harris, but the formation of discursive analysis as a discipline took place in the 1970s. These years basic American works which connected a discourse analysis with traditional linguistic themes were published. These are researches ofW. Labov, J. Grimes, R. Langaker, T. Givon, W. Chafe.

The main contribution of $W$. Labov was the study of not individual sentences, but of the whole narratives, and the discovery of the principles of the theory of discourse. W. Labov and his students discovered for the linguistic community the phenomenon of oral personal narratives, that is, the man's story of experiencing, his own significant experience.

According to the intention of the author of the study should have not linguistic, but welfare orientation. To solve these new problems, W. Labov needed a new theoretical apparatus, and this is why these studies, according to many scholars, were the beginning of the existence of oral discourse as a complete object of linguistic description. The works of W. Labov did not open the phenomenon of "discourse", but became a catalyst for the need to take into account discursive phenomena in theories of language [5, p. 14].

No less important contributions to the development of discourse analysis were made by such scholars as J. Grimes, R. Langacker and T. Givon.

In particular, J. Grimes in his work "TheThreadofDiscourse" revealed the connection of discourse with generative semantics [3, p. 20].

It was interesting to mention that the language was considered by the scientist in two respects: firstly, as a decision that takes the speaker on what to say and what is not, and, secondly, as mechanisms and structures that are available to the speaker to implement those decisions in order to communicate with another person. In turn, R. Langacker, who is considered one of the founders of cognitive linguistics and the creator of cognitive grammar, revealed the inalienable and profound connection of the linguistic structure and discourse [4, p. 10]. The Cognitive Approach as it takes into account the humansmemory, attention and perception and the ways how they influence on the behavior of a person. But at the same time human behavior is a product of all the processes working together and not just separate parts.

$\mathrm{T}$. Givon is one of the founders of the discourse-oriented approach to syntax. The main idea of T. Givon's concept is that grammar is a set of instructions for the mental processing of discourse that a speaker gives the listener. It is one of versions of a thesis that the grammar submits to communicative processes [5, p. 30].

Quite interesting are the views of W. Chafe, who emphasized the unconditional connection of language and consciousness. According to him, language and mind belong to a single system that makes us human, along with other human qualities, such as imagination, memory, and social interaction. 
Contrary to constructivist currents in linguistics, W. Chafe considered language as a very complex phenomenon, which is inseparable from the natural context in three physical forms: speaking, writing, and thinking. His glance at the language was evolutionary: "Each type of language usually uses the type of language that best encodes what consumers of this type of language consider to be the most appropriate" [5, p. 15].

But he did not stop at this, in his book "Discourse, Consciousness and Time: Transfer and Movement of Conscious Experiences in Oral Speech and Writing", the scientist reflected the connection between types of linguistic discourse and types of conscious mental actions with different levels of transference. This work offers a comprehensive picture of the dynamic natures of language and consciousness that will interest linguists, psychologists, literary scholars, computer scientists, anthropologists, and philosophers.

Results. The origins of discourse analysis as a discipline were laid in the early 20th century. The traditions of the American ethno-linguistic school, founded by F. Boas, and Czech structuralism, the emergence of which is associated with the Prague linguistic circle under the leadership of W. Mathesius.

At the same time, the formation of the discipline of discursive analysis took place in the 1970's and was associated with the activities of such wellknown American linguists as W. Labov, J. Grimes, R. Langacker, T. Givon, U. Chief.

\section{References:}

1. Gumbol`dt V. (1984). Izbrannye trudy po yazykoznaniyu [Selected works in linguistics]. Moscow : Progress. (in Russian)

2. Hrolenko A.T., Bondaletov V.D. (2006). Teoriya yazyka : Uchebnoe posobiye [The theory of language]. Moscow : Flinta. (in Russian)

3. Grimes Joseph E. (1972). The Thread of Discourse. New York : The A-book.

4. Langacker Ronald (2005). Discourse in Cognitive Grammar. Washington : Freetime.

5. Chafe W. (1994). Discourse, consciousness and time: The flow and displacement of conscious experience in speaking and writing. Chicago : University of Chicago Press. 